\title{
79- Postmodernizm ve çeviri: Postmodern söylem içerisinde çevrilemezlik kavramı
}

Gökmen GEZER

Funda KIZILER EMER²

APA: Gezer, G.; Kızıler Emer, F. (2021). Postmodernizm ve çeviri: postmodern söylem içerisinde çevrilemezlik kavramı. RumeliDE Dil ve Edebiyat Araştırmaları Dergisi, (25), 1281-1300. DOI: 10.2900o/rumelide.1032593.

\section{$\ddot{O} \mathbf{z}$}

Bu makale, çevrilemezlik kavramının ne'liğini, kavramsal ve kuramsal açınımını ve milenyumun çeviri tarihi içinde başat konumdaki postmodern çeviri yaklaşımlarının çeviri pratiği açısından nasıl bir öneme sahip olduğunu ortaya koymayı amaçlamaktadır. Bu makalede, günümüzün çeviri kuramlarını belirleyen postmodern/ postyapısalcı söylemin temsilcisi konumundaki, Derrida'nın yapıbozumcu/yapısökümcü çeviri yaklaşımı ışığında, anlamın belirsizliği ve dolayısıyla çevirinin imkan(sızlık)ları fikri tartışılmaktadır. Belirsizliğe/ kesinsizliğe, farklılığa/ ötekiliğe ve her anlamda çoğulculuğa vurgu yapan postmodern söylem için, Babil söylencesindeki içerik ve dillerin karışıklığ teması, ayrıcalıklı bir mekân olarak ortaya çıkmaktadır; çünkü Babil, hem insanlar/toplumlar arası iletişimin, kültürel alış-verişin gerçekleşebilirliğine hem de altüst olup yıkılabilirliğine sahne olan; metinler, diller, gelenekler ve kültürler arasındaki ilişkilerin antagonistik yapısını ortaya koyan bir uzamdır. Çeviri de postmodern söylem gibi, bu antagonistik arada kalma ve belirsizlik durumuyla karşı karşıyadır: kaynak metinle erek metin arasında, birinin diğerini tanıması adına, anlama aracılık etmektedir; her ikisi de anlamın, dolayısıyla çevirinin istikrarsızlığı üzerinden söylem üretmektedirler. Söylemlerinde metinlerarası bağlama vurgu yapılmakta ve her zaman başka metinlerin ve bağlamların izlerini taşıdıkları iddia edilen çeviri metinlerin özerk oluşumlar olduklarının altı çizilmektedir. Çağa egemen postmodern söylem içinde çeviri bu nedenle, orijinalin yeniden üretimi değil, yeniden inşası olarak kavramsallaştırılma aşamasına gelmiştir. Metinlerin yeni bakış açılarıyla okunması anlamına gelen bu duruma göre, Derridacı yapıbozum stratejisinin öngördüğü gibi, anlamın sınırsızlık hali ortaya çıkmakta ve daimî olarak yeni anlam katmanları belirmektedir. Beliren anlam katmanlarının aktarılmasındaki açmaza yönelik her çözüm çabası da bir çevrilemezlik durumuna karşılık gelmektedir. Çevrilemezlik kavramının postmodern söylem içindeki yerini aydınlatmayı hedefleyen bu çalışmada, öncelikle postmodernizm kavramı ele alınmış ve daha sonra postmodern söylemin çeviri üzerindeki etkisi tespit edilmeye çalışılmıştır. Çalışmanın sonunda, çevrilemezlik kavramının, anlamın sonsuza kadar ertelendiğini, sabit kalmadığını ve farklı siyasal ve bilişsel arka plana göre her okumada yeniden belirlenip inşa edildiğini açı̆̆a çıkaran postmodern söylem ile yakın bir ilişki içinde olduğu ortaya konulmuştur.

Anahtar kelimeler: Çeviri, çevrilemezlik, postmodernizm, yapıbozum, Derrida

Dr. Öğr. Gör., Galatasaray Üniversitesi, Yabancı Diller Yüksekokulu (İstanbul, Türkiye), ggezer@gsu.edu.tr, ORCID ID: o0oo-0003-2224-8034 [Araştırma makalesi, Makale kayıt tarihi: 18.09.2021-kabul tarihi: 20.12.2021; DOI: 10.29000/rumelide.1032593]

$2 \quad$ Doç. Dr., Sakarya Üniversitesi, Fen-Edebiyat Fakültesi, Çeviribilim Bölümü (Sakarya, Türkiye), fkiziler@sakarya.edu.tr, ORCID ID: 0000-0003-2204-3063 


\title{
Postmodernism and translation: The concept of untranslatability in postmodern discourse
}

\begin{abstract}
This article aims to reveal what the concept of untranslatability is, what its conceptual and theoretical implications are, and how important postmodern translation approaches are, as holding a dominant position in the translation history of the millennium in terms of translation practice. In this article, in the light of Derrida's deconstructionist/deconstructionist translation approach, which is the representative of the postmodern/poststructuralist discourse that determines today's translation theories, the idea of the indeterminacy of meaning and therefore the (im)possibilities of translation are discussed. For postmodern discourse, which emphasizes uncertainty/indefiniteness, difference/otherness and pluralism in every sense, the content in the Babylonian myth and the theme of languages being confounded emerge as a privileged site; as of yet, Babylon is an extension of both the realisability and destructibility of human/inter-communal communication and cultural exchange as well as a location that reveals the antagonistic nature of relations between texts, languages, traditions and cultures. Translation, like postmodern discourse, is faced with this antagonistic situation of "in-betweenness" and indeterminacy, thereby mediating the meaning between the source text and the target text so that one can recognize the other. Translation is always a "hybrid" by character and both translation and postmodernism produce discourse on the instability and inscrutability of signification in language and therefore of translation. In their discourses, the emphasis is placed on the intertextual context and it is underlined that the translated texts, which are claimed to always carry the traces of other texts and contexts, are actually autonomous formations. Translation has thus come to be conceptualized within the contemporary postmodern discourse as a rewriting, not as a reproduction of the "original. According to this situation, which means reading the texts from new perspectives, as predicted by the Derridean deconstruction strategy, there emerges a state of infinity of meaning and new layers of meaning are constantly appearing. Every effort to resolve the impasse in the transfer of the emerging layers of meaning also corresponds to a situation of untranslatability. In this study, which aims to illuminate the place of the concept of untranslatability in postmodern discourse, the concept of postmodernism is firstly discussed and then the effect of postmodern discourse on translation is tried to be determined. At the end of the study, it is revealed that the concept of untranslatability is in close relationship with the postmodern discourse, which reveals that the meaning is postponed forever, that it never remains fixed, and that it is redefined and reconstructed in each reading according to different political and cognitive backgrounds.
\end{abstract}

Keywords: Translation, untranslatability, postmodernism, deconstruction, Derrida

Everything starts with translation, because it must.

Jeffrey Sacks (2011:1001)

\section{Giriş}

Anlamın çokluğu ve metinlerin bütüncül, tek anlamlı gerçekler içerdiklerinin reddi çeviribilimin uzun zamandır gündemine aldığı konuların başında gelmektedir (Benjamin 1955, Steiner 1975, Arrojo 1994, Pym 1995, Jones 2004). "Çevrilemezlik" kavramı ile birlikte bu makalenin bir diğer temel öğesi olan postmodern söylem ve okuma pratikleri, çevirinin de gündeminde olan bir metnin okura ve okuma 
şartlarına göre birden fazla anlamı olabileceği görüşünü savunmaktadır. Bu görüş, Quine’in “çevirinin belirsizliği” tezinde ileri sürmüş olduğu "çevrilemezlik” temalı gerekçelerle örtüşmektedir (1960: 26). Andrew Chesterman, "orijinal anlamın sabit kalmadığı ve dolayısıyla sürekli ertelendiği bu postmodern fikri “aşırı” bulduğunu belirtmekle beraber, çevirinin “orijinal” olan ile aynı, fakat “orijinal”den farklı da olamayacağı görüşünü savunan Aristoteles'in çelişkisini yaşamaktadır (1997: 57). Bu çelişkinin nedeni, çevrilemezlik kavramının da beslendiği, dil göstergelerinin nedensizliği, sabitlenemez oluşu ve belirsizliği gibi olgulara dayanmaktadır.

Geleneksel çeviri anlayışının, çeviriyi daimî olarak mümkün gören anlamın birliği savından, son yirmi yılda, anlamın belirlenemezliğini ve çoğulluğunu vurgulayan bir karaktere evrilmesi, çeviri alanında "çevirilemezlik" kavramı üzerine birtakım çalışmalar yapılmasına neden olmuştur. Bu dönemde, Fransız filozof Barbara Cassin ve Amerikalı kuramcı Emily Apter tarafından kaleme alınan ortak bir çalışma ürünü Dictionnaire des Intraduisibles (2004), alanda 'çevrilemezlik' kavramına dikkat çeken ilk eserler arasındadır. Çevrilemezlik kavramının doğrudan ele alındığı ilk eser, Apter’in Dünya edebiyatındaki mutlak çevirilebilirlik varsayımını konu ettiği Against World Literature: On the Politics of Untranslatability (2013) başlıklı kitabıdır. Trinity College tarafından 2015 yllında yayınlanan Varieties of Untranslatability başlıklı makale, çevrilemezlik tartışmasını kavramın çeşitlere ayrıldığı aynı zamanda nedenlerinin üzerinden çözüm stratejilerinin sunulduğu bir noktaya taşımaktadır. East Anglia Üniversitesinin 2015 yllında düzenlediği The Sixth International Postgraduate Translation Symposium isimli etkinlikte sunulan "Untranslatability Interdisciplinary Perspectives" başlıklı bildiride kavramın kuramsal ve felsefi yönleri vurgulanmıştır (Large, Akashi, Jozwikowska vd., 2019: 6).

American Comparative Literature Association tarafindan 2013 yllnda düzenlenen konferansta ise Friedrich Nietzsche ve Jacques Derrida gibi filozofların fikirleri tartışmaya açılarak; dil kullanımının, dilbilim, edebiyat ve felsefenin çeviriyle olan doğal birlikteliği gündeme getirilmiştir. Tek ve değişmez bir hakikatin olmadığını, aksine hakikatin yorumlanarak inşa edildiğini savunan Friedrich Nietzsche, "Über Wahrheit und Lüge im außermoralischen Sinn" (İng. "On Truth and Lies in a Non-moral Sense") başlıklı yazısında, dillerin çeşitliliğini çevirilemezlik kavramıyla ilişkilendirmiş ve bu ilişkiyi günümüzde postmodernist düşüncenin faydalandığ - hakikat ve görecelik gibi kavramlarla birlikte değerlendirerek bir anlamda kavramın temellerini atmıştır ([1873] 2019: 5).

20. yüzyılın ikinci yarısından itibaren varlık gösteren postmodern felsefi söylem iki temel kaynaktan beslenmektedir: Bunlardan biri varoluşçu felsefenin önemli temsilcilerinden olan Martin Heidegger'den miras alınan ontolojik yaklaşım, diğeri "dil(in) felsefesi” olarak adlandırılan yaklaşımdır. Hakikatin durağan değil, sürekli yeniden inşa edilen devingen bir kavram olarak ele alınmasında Ludwig Wittgenstein'ın Tractatus Logico-Philosophicus adlı kült metninde kavramsallaştırdı̆̆g “dil oyunları” kavramı başroldedir (1921: 5.62).

Wittgenstein'ın, kabaca dilin kullanımındaki belirsizlikleri imleyen "dil oyunları" ("Sprachspiele") kavramını en etkin biçimde kullananların başında, post-modern ve post-yapısalcı söylemin öncüleri olan Jean-François Lyotard ve Jacques Derrida gelir. Derrida bu kavramı, "erteleme ya da anlam yaratma veya fark yaratma süreci” olarak bilinen différance terimiyle karşlamayı seçmiştir. Derrida, "Who or What Is Compared? The Concept of Comparative Literature and the Theoretical Problems of Translation" başlıklı makalesinde, anlam yaratma sürecini ya da anlamın ertelenmesi durumunu çeviriye bir direnç gösterme olarak yorumlamış ve örneklerinde karşılaştırmalı edebiyat bağlamında özel isimlerin çeviri güçlüğüne ve hatta imkansızlığına değinmiştir (Derrida \& Prenowitz, 2008: 37). 

1300)

Modernizmi irasallaştıran her tür temel ilkeyi kökten biçimde sorgulayan postmodern söylem; "belirsizlik", "farklılık", “ötekilik” ve "çoğulculuk” gibi unsurları birer sacayağı olarak belirlemiştir (Hassan, 1983: 9; Kızıler, 2006: 140-151; Tural, 2018: 30). Başlangıçta kültürel alış-verişin cereyan ettiği, ancak dillerin karışması lanetiyle birlikte kültürlerin altüst olduğu kaotik bir uzam olarak, tüm bu unsurları metaforik düzlemde somutlaştıran Babil, postmodern söylem ile çeviri etkinliğinin buluştuğu ayrıcalıklı bir mekân görünümündedir. Çeviri sahası, Babil sonrası dillerin çokluğu ve karışıklığı durumuyla, postmodernizme uygun düşen bir temsil sunmaktadır: Çeviri mecrasında da postmodernist anlayışta olduğu gibi, kültürler ve diller arası ayrımlar şüpheci, ironik veya reddedici tavırlarla ele alınabilmektedir.

Çeviri edimi de postmodern söylem gibi bir belirsizlik, bir tür arada kalma durumu içinde varlık bulur: kaynak metinle erek metin arasında kalan çeviri, anlama aracılık etmektedir. Anlamın belirsizliğinin, sabitlenemezliğinin, çoğulluğunun ve dolayısıyla çevirinin istikrarsızlı̆̆ının dile getirildiği postmodern söylemlerde, metinlerin daima başka metinlerden ve bağlamlardan izler taşıdıkları ileri sürülmektedir (Kristeva, 1980: 36; Aktulum, 2000: 41). Postmodernizm gibi hibrid bir özellik taşıdığı görülen çeviri eylemi, kaynak ve erek dil sistemlerinin her ikisinin de taleplerini yerine getirmek adına iki beklenti arasına sıkıştırılmıştır: Birinde diğer olanı anlaşılır kılması ve diğerinde, göstergenin değişkenliğinin tartışmaya açarak, anlamı ortaya çıarması beklenmektedir.

Bu haliyle çeviri, hibrid-melez bir dokuya sahiptir ve çeviri bir metin de - adeta bir tür palimpsest gibi - daima diğer metinden ve bağlamdan izler taşımaktadır. Bu nedenle, postmodern söylem içerisinde çeviri, orïjinal bir metnin yeniden üretilmesi değil, ancak yeniden yazılması olarak kavramsallaştırılmıştır. Roland Barthes'ın "The Death of the Author" (1967) adlı makalesinde işlediği "yazarın ölümü” metaforu bu bağlamda, "okurun doğumu" ve dolayısıyla çevirmenin "doğumu" anlamına gelmektedir. Barthes'ın değindiği gibi, bir okur olarak çevirmen metni tek anlamllıktan kurtarmaktadır (1977:142-149). Yazarın metin üzerindeki mutlak yetkisini silen bu anlayışa göre, anlamın çoklu algılanması ve o şekilde yayılması üzerindeki engeller kalkmıştır.

Metnin çoklu algılanması bir anlamda, Jacques Derrida'nın “The Ear of the Other” adlı eserinde detaylı açıkladığı gibi, dillerin "katışıksız" olmadığı gerçeğine karşılık gelmektedir. Bu katışıksız / arı olmama durumu da çevirinin üstesinden gelemeyeceği bir ortam oluşturmaktadır. Bu ortamda, diller arası farklılıkların anlamlı kılınması için yine farklı bir anlam katmanından faydalanılmaktadır. $\mathrm{Bu}$ farklılıklar veya bölünmeler çevirinin asıl var olma nedeni olup doğal olarak çeviri pratiğini çevirmenin müdahalesine açık hale getirmektedir. Böylece her çeviri eylemi kendi içinde yeni bölünmelere yol açmaktadır (Derrida, 1985: 134-135).

$\mathrm{Bu}$ süreçteki temel bölünme çevrilebilir ile çevrilemez arasında gerçekleşmektedir. Orijinal metin içerisinde var olma koşullarını yakalayan çeviri eylemi çevirinin mümkün olduğunu, yani çevrilebilirliğini dolayısıyla çevirinin evrenselliğini vurgulamaktadır. Diğer yandan, her çeviri ediminin bir dizi dışlamaya dayandığı gerçeği çevirinin kendisini kaçınılmaz olarak bir öteki olma durumuna sokmaktadır (Iser, 1995: 32). Evrenselliği reddeden bu postmodern yaklaşım çevrilemez olanı vurgulayan yaklaşımdır.

Çevrilebilir olanın saptanabilmesi çevrilemez olanın çeviri ortamından uzaklaştırılmasıyla mümkündür. $\mathrm{Bu}$ uzaklaştırmaya rağmen çevrilemez olanın ontolojik izleri kaybolmayacaktır. Bu izler çevrilebilir ile çevrilemez arasındaki çizgiyi belirsiz ve kararsız kılmaktadır. Çeviri sürecindeki bu anlar çeviri 
kararlarının her zaman mantıklı bir düşünme sonucunda alınmadığını gösteren anlardır; çevirinin yalnızca bir eşdeğerlik arayışı olarak tanımlanamaz olduğuna işaret etmektedirler.

Bu makale çevrilemezlik kavramının ne'liğini ve postmodern söylem ile ne denli yakın bir ilişki içinde olduğunun tespitini yapabilmek için kaleme alınmıştır. Bu amaca koşut olarak makalenin ilk aşamasında temel bileşenleriyle postmodernizm kavramı incelenmiş, ikinci aşamasında ise postmodern söylemin çeviri üzerindeki etkileri sorgulanmıştır. Çevrilemezlik kavramının tanımlanmasına, kavramsal ve kuramsal gelişimine ışı tutmaya odaklanan çalışma, kavramın postmodern söylemle yakın ilişkisini ortaya koymayı ve hatta günümüzdeki çeviri yaklaşımlarının bu kavramla par excellence bir sunumunun sağlandığını göstermeyi hedeflemektedir. "Çevrilemezlik" kavramının ya da "çevirinin imkansızlı̆̆ı” savının biçimlenmesinde anlamın sonsuza kadar ertelendiğini savunan postmodern söylemin belirleyici rolünü göstermede, postyapısalcı Jacques Derrida'nın yapısökümcü / yapıbozumcu yaklaşımı kilit bir konumdadır. Bu nedenle yöntemsel olarak bu stratejinin açımlanmasına ağırlık verilmiştir.

\section{Postmodernizme özet bir bakış}

Postmodern kavramı ilk olarak yirminci yüzyılın sonlarına doğru, 1870'lerde, İngiliz ressam ve sanat eleştirmeni John Watkins Chapman tarafından kullanılmıştır (Welsch, 2002: 12-13). Modern sözcüğünün önüne getirilen "sonra" anlamına gelen post- önekiyle oluşturulan postmodern kelimesi, kavram olarak sözlük anlamıyla değerlendirilmekte ve bir "esinlenme" ürünü olarak görülmektedir (Menteşe, 1992: 217). Ancak kavramın kesin bir tanımını yapmak mümkün gözükmemektedir (Timur, 1999: 321; Skeggs, 1991: 257).

Kabaca modern-sonrası anlamına gelen post-modern, adının ayrılmaz bağlaşığı olan modernle antagonistik bir ilişki içindedir. Onun devamı mıdır ya da köktenleşmesi midir, yoksa ondan bir kopuş mudur? vb. şeklinde bir dizi soru işareti içeren kavram, her şeyden önce II. Dünya Savaşı sonrasında batı dünyasının girdiği çok boyutlu bir kriz sürecinin bir doğurgusudur. Gaz odaları ve toplama kampı paradigmasıyla özdeşleşen bu savaş, - özellikle 17. yüzyll ila 20. yüzyll arasında bilimsel, teknolojik, ekonomik, ideolojik bağlamda dünya çapında elde ettiği rakipsiz erk neticesinde her alanda ve her anlamda kendini merkezi bir noktada konumlandıran - batı uygarlığının tüm ülkülerinin açı ve reddedilemez biçimde ihlal edildiğini belgeler. Postmodern, modern batı uygarlığının Aydınlanma, ilerleme, Marksizm gibi "büyük/meta" ya da "üst-anlatılarının" güvenirliğini yitirmesiyle birlikte, onun ekonomik, politik, ideolojik ve sosyolojik bağlamda üretip meşrulaştırdığı her tür üst anlatıya karşı derin bir inanılmazlık ve kuşku içeren söylemler üretmesiyle tanımlanmaktadır (Lyotard, 1979/1984: xxiii-xxiv). O halde postmodern/postmodernizm kavramı öncelikli olarak, 20. yüzyılın ikinci yarısında modernizmi yasallaştıran tüm temel yapı taşlarının yerinden edilerek ölümünün ilan edildiği kökten bir özdüşünümsellik sürecini imler (Kızler, 2006: 127-138).

Postmodernist söylem, Michael Dear'a göre, "üst anlatılara" karşı bir kuşkuyu, modernizmin "temelci" epistemolojisine bir saldırıy ve insan bilgisi için nihai temellerin veya nihai gerekçelendirme olasıllklarının reddiyesini içermektedir (Dear, 1988: 271). Modernizmin temellerine yönelik ilk ciddi reddiyeyi ortaya koyan Nietzsche, sırasıyla modern metafizik düşünceyi, bilgi ve hakikat anlayışını eleştirmiştir ki, çağını aşan bu fikirleriyle postmodernizmin de öncüsü sayllır. Ona göre hakikat kavramı evrensel ve değişmez değil, tarihsel süreç içinde değişen siyasal-toplumsal düzen, başat değerler ve türlü çıar ilişkileri çerçevesinde sürekli yeniden kurgulanıp-tasarlanan bir kavramdır (Küçükalp, 2017: 861). $\mathrm{Bu}$ düşüncelerin hepsinin sonradan postmodernizm kavramına transfer edildiği görülmektedir. 

1300)

"Geç kapitalizmin mantığının kültürel başatlığı" (Jameson, 1994: 76) olarak postmodernin düşünce, sanat, edebiyat ve çeviri etkinlikleri alanına sirayetiyse; dil'in - özellikle "Yazarın ölümü” (Barthes [1979]1968/1977: 142-149) bildirisiyle birlikte, ad ve yasa koyucu (Tanrısal konumdaki) özneden de özerkleşerek - hiç görülmemiş bir özgürlük kazanması şeklinde olur. Artık yazarının olmadığı dil, tüm galaktik evreni ele geçirmiş, dil ise her şeyi metne çevirmiştir: Artık "her şey metindir" (Derrida 1997:158). Parla'nın söylemiyle "metnin dışında bir şey yoktur. Metin veya dil ise, hangi söylemin parçası olduğuna göre sürekli değişen anlam göstergeleri oluşturur." Bunun anlamı, anlamın "sabit" olmayışıdır (2000: 336). "Yazarın ölümü” ve "her şey(in) metin” olması paradigmaları çerçevesinde "metinlerden metinlere, göstergelerden göstergelere açllan ve açlldıça kapanan, bitimsiz bir devinim içinde gezinen, hiçbir zaman ele geçirilemeyecek, dizginlenemeyecek, hepçileyin ertelenmiş olacak olan 'anlam'ı yaratan yazar değil [...] 'okur'dur" (Kızıler, 2006: 30). O halde artık anlam gibi “(m)etni yaratan (da) "artık yazar değil, alımlama sürecinde, daha doğrusu her bir okuma ediminde yeniden inşa eden/ kuran okur'dur” (Kızler Emer, 2019: 229). Yazınbilim bağlamında alımlayıcı konumundaki 'okur' ön plana çıkarken, çeviribilim açısından ise metni alımlayıp yeniden üreten 'okur' konumundaki 'çevirmen' öne çıkar.

20. yüzyılın ikinci yarısından itibaren dil ve gerçeklik arasında temsil bağı olduğu savının çöküşüne koşut olarak değişmez hakikat anlayışı da çökmüş ve önceden derin yüzeye şifrelenmiş biricik bir hakikati olduğu varsayllan metinleri tekil okuma modelleri artık yerini çoğul okuma modellerine bırakmıştır. Bunların başında gelen Derridacı yapıbozumla birlikte “'metin' diye adlandırılan yapıtlar, köktenci ve hiç durmayan sonsuz bir anlamlar oyunu boyunca, değişmez bir anlam ve doğrunun ötesinde açımlan(maya)" başlamıştır (Sarup 1997: 86-87).

Postmodernizm kesintisiz biçimlenmeyi ve çelişkiyi insan kimliğinin ayrılmaz bir parçasına dönüştürmektedir (Aksoy \& Aksoy, 1992: 58). Eleştirel söylem üreten bir makinenin çalışma prensiplerine sahip olan postmodernizm, Jean-François Lyotard'a göre, üst-anlatıları yok etmek ve buna karşılık yenilerini inşa etmek hedefindedir. Benzer şekilde postmodernist felsefe kuramlarıyla anılmakta olan Derrida'nın yapısökümü, hakikatin değişmezliği inanışıyla ikili karşıtlıklar üzerine kurulu Batı felsefe geleneğini eleştirmektedir (Munslow, 1997/1998: 25). Bu yaklaşımla Derrida, düalist bir yapıya sahip Batı düşünme mantığının içerdiği gösteren-gösterilen, konuşma-yazı, erkek-kadın gibi tüm ikili karşıtlıkların aslında birbirini dışlamakta ve hiyerarşik bir ötekilik mantığı içerisinde kurgulandı̆̆ını göstermektedir (Derrida, 1982: 32).

Postmodernizmin öncüsü olan Jean François Lyotard, bilginin kuramsallaştırılması meselesini Wittgenstein'dan ödünç aldığı "dil oyunları" kavramıyla ele almaktadır. Dil oyunları kavramını Jacques Derrida, anlamın ertelenme sürecini adlandırmak için kullandığ différance kavramıyla karşılamaktadır: Derrida'ya göre, bir metnin içinde, metne bulunduğu şekli veren, kabul edilmiş veya bastırılmış anlam alt-katmanları, yani "mevcudiyet metafiziği”" bulunmaktadır. Metinler, yazarların niyetlerine karşıt kaynaklar sunarlarken, nedir sorusuyla kimliği/ özdeşliği ve ne değildir sorusuyla farklılı̆ı ortaya çıkaran anlamlandırma sürecini başlatırlar. Anlamın bu sorgusunda, her seferinde bir başka kavrama gönderme yapılması nedeniyle anlam sürekli olarak ertelenmektedir. (Derrida, 1982: 2526). Bu nedenle dile hiçbir zaman tam olarak hâkim olunamadığını savunan postmodern söylem, ontolojik ve epistemolojik temelli tüm felsefi sorgulamaları "metin" üzerinden gerçekleştirmektedir. Postmodern söylem içerisinde metin, çok sayıda yeniden okuma sağlayan bir kaynak olarak görülmektedir. Bu nedenle bir metnin, kaynak metne sadık kalınarak nasıl çevrilebileceği sorusu yanitsız kalmaktadır. 
Postmodernist bakış ile birlikte, tüm belirleyici söylemler bir bağlam içinde analiz edilmekte ve dış gerçeklik kuşkuyla karşılanmaktadır. Nesnelin temsil edilebilirliği kabul görmediği postmodernist söylemde, sözcüğün asıl anlamının, dildeki kullanımında olduğu söylemi (Wittgenstein, 1986: 20), postmodern yaklaşımda, "neyin anlatıldığı değil, nasıl anlatıldı̆̆ı" ilkesiyle tekrar edilmektedir. Postmodern söylem okuru, gerçekliğe bağlı olmayan labirentsi göstergeler yığını içerisinde yönlendirmektedir. Derrida ise, anlamın birden fazla yoruma ihtiyacı olduğunu söyleyerek, postmodernin çokanlamlılığını özetleyen bir tespitte bulunmaktadır.

Tüm bunlar ışığında, postmodernizmin ekonomik, sosyal ve kültürel özellikleri derlendiğinde ortaya şöyle bir tablo çıkmaktadır:

a. Postmodernizm,

- modernizme karşı sorgulayıcıdır (Dear, 1988: 271).

- evrensel bütünsellik yerine, çoğulculuktan yanadır (Welsch, 2002: 4; Ecevit, 2001: 69; Kızller, 2019: 230).

- her alanda tam bir eklektizm (seçmecilik) anlayışı sergiler (Featherstone, 1988)

- görecelilik tavrını benimser. (akt. Kielkiewicz, 2015:51; Rorty 1983; Lyotard 1993)

- gerçekliğin yerine imgeyi koyar; zit kavramlar kullanılır (Smart, 1993: 108)

- gerçekliği sorunsallaştırır (Smart, 1993: 12-39)

b. Postmodernizm'e göre,

- gerçeklik karmaşıktır; dil gerçekliği yansıtamaz (Rorty, 1982: 287)

- gerçeklik holistik, harmonik ve açık değildir (Sim, 1999: 243- 244)

- $\quad$ çok gerçek ve çok anlam vardır (Hebdige, 1986: 78).

Siralanan bu pek çok nitelikten, özellikle hakikat vurgusunun geçtiği düzlemlerdeki epistemolojik felsefeye dayalı ön kabuller; farklılık, farklı okuma ve çoklu yorumlama, görelilik, çoğulculuk, dil oyunları ve belirsizlik gibi temalar postmodernizmin üzerinde söylem geliştirdiği ana konular olarak öne çlkmaktadır.

\section{Postmodern söylemin çeviri üzerinde nasıl bir etkisi vardır?}

Çeviri disiplininin sınırlarını, son yıllarda, Batı geleneklerinin ötesine genişletme çabası kapsamlı bir çeviri tarihi için çoğulcu bir yaklaşımın temellerini atmıştır. Çeşitli dillerin ve farklı kültürlerin çeviri tarihlerinin incelenebildiği post-sömürgecilik, feminizm, ideoloji, küreselleşme, çeviri etiği, minör edebiyat ve kültürel çalışmalar gibi tamamı postmodernizmle ilgili araştırma paradigmaları sayesinde bu yolda ilerlemeler kaydedilmektedir. Bu paradigmalardan yirminci yüzyılın sonlarına doğru ortaya çıan Derridacı yapıbozum stratejisi, yerleşik modernist varsayımları eleştirmekte ve bunların kültürel dayatmaların ve güç-iktidar ilişkilerinin birer sonucu olduğu yorumunu yapmaktadır. 

1300)

Postmodern anlayışın belirsiz doğasının bilincinde olan yapısökümcü yaklaşım, dilin nasıl kullanıldığı sorusunu, dilin daha çok temsil etme potansiyelini ön plana çlkararak ele almaktadır. Gerçekliğe işaret etmekten ziyade onu temsil görevi gören dil, bu yaklaşıma göre, gerçeği sosyal, tarihi, kültürel ve güçiktidar ilişkilerinin bir yansıması olan politik-ideolojik bakış açlarına göre tasvir etmektedir. Postmodern söylem ile postyapısalcı ve yapısökümcü yaklaşım arasında dil ve gerçeklik açısından ön görülen bu türden bir ilişki, aynı zamanda çeviri için önem arz etmektedir.

Çeviri, olguları ifadelere dönüştüren bir eylem olarak, kendi sürecinde çevirmenin yorumlarının müdahalesiyle biçimlenmektedir. Bu açıdan bakıldığında, yapısökümcü yaklaşımda çeviri metin, "müdahale" edilmiş bir ürün görümündedir (Eser, 2014: 112; Hermans, 1997: 42). Bu yaklaşımda hakikatin aktarılmasında çevirinin oynadığı rolün sorgulanması yapılmaktadır. Nietzsche ve postmodern düşünce çizgisinde yapısökümcü yaklaşıma büyük katkılar sağlayan Foucault, hakikatin ne'liği sorusunu Batı felsefesinin temel sorunu olarak görmüş ve gerçeklik kavramını güç-bilgi denklemi içinde değerlendirmiştir. Foucault’a göre bilginin getirdiği güç, gücün kontrol ettiği düşünce içinde, bulunduğu bağlama göre, dilin anlam yaratma gücünü ve potansiyelini etkilemektedir (1994: 35). Değişkenlere bağlı olarak güç/bilgi denkleminin neyi eklemleyip neyi "ötekileştirdiği” değişecek ve böylece birden fazla yazın-birden fazla çeviri üretmek mümkün olacaktır.

Ferdinand de Saussure'ün getirdiği dil-söz (langue-parole) ayrımını ve anlam-biçim arasındaki "nedensizlik" ilişkisini dikkate alan Foucault ve Derrida gibi isimler, deneyimlerin ifade edilmesini şekillendirmede veya belirlemede dilin önemini vurgulamaktadırlar. Sosyal bir gerçeklik olarak dil, kendisine sürekli olarak yeniden yüklenen sosyal anlamlarla birlikte, güç ilişkilerinin sosyal yapıyı inşa etmesinde belirleyici bir rol oynamaktadır (Foucault, 1980: 51). Bu özelliği dili kaçınılmaz olarak ideolojik bir enstrümana dönüştürmektedir. Bu nedenle anlam sadece gösteren-gösterilen ekseninde değil, göstergeler bütününde aranmalıdır. Göstergelerin oluşturduğu metin, anlamın ancak çıkarım sonucunda elde edilmesine, dolayısıyla yeni bir metin ortaya çıkmasına imkân vermektedir.

Metnin farklı yorumlanmasıyla ortaya çıkan yeni metin aynı zamanda manipülasyona açık olabilmekte ve çeviri doğası gereği farklı olanın, yani ötekinin dilini bozma eğilimi gösterebilmektedir (Derrida, 1978: 125-148). Çeviri yoluyla gerçekleşen öteki dille temasın bir bozulmaya yol açması çeviriye olan ihtiyacı daha da artırmaktadır. Bu nedenle Roman Jakobson, her şeyin çevrilebilir olduğunu savunurken, özellikle şiirde ses ve sözcük katmanlarında gerçekleşebilecek bozucu eğilimleri düşünerek, bu anlamda uygulanılacak çeviri stratejisiyle ilgili olarak "yaratıcı aktarım-değiştirme" ifadesini kullanmak zorunda kalmıştır (1959: 238).

Derrida'ya göre heterojen, farkhlaş̧an ve yoruma açık bir olgu olarak metin her şeydir ve onun dışında hiçbir şey yoktur (1997: 158). Yoruma açık çok katlı yapısı nedeniyle metnin açık ve net bir anlamının bulunduğu fikrine şüpheyle yaklaşmaktadır; ona göre her metin "yerine getirilmeyen bir söz" niteliğindedir (Moran, 2008: 453-454). Böylece dil göstergelerinin sınırsızlığına vurgu yapılmakta ve tek bir gösterilenden değil, gösterge sisteminden söz edilmektedir. Böylelikle anlam içeriğinin başka bağlamlar yoluyla genişlemesine işaret edilmektedir (akt. Sarup, 1993:52); bağlamın değişmesiyle gösterge döngüsündeki gösterenler zinciri değişmekte ve beraberinde anlam da değişmektedir (Sarup, [1997] 2004: 54).

Derrida'nın yapısökümcü kuramı, kendisi postmodern olarak tanımlamasa da veya postmodern kelimesini kullanmasa da, çağdaş çeviri kuramıyla ilgili en yakın postmodern düşünce konumundadır. Yapısökümün bir "sistem” olarak görülmesini isteyen Derrida (1978: xiii), Saussuere’ün, "dilde yalnız 
ayrılıklar / farklılıklar vardır" ilkesiyle örtüşen différance kavramını yapısökümün ana tasarımı olarak belirlemiştir (1978:292). Derrida différance terimini bir "ayrım ve erteleme" ilkesine dayandırmakta ve terimi, anlamın daima başka bir yerde, zaman ve konum olarak, ertelenmiş olduğunu vurgulamak için kullanmaktadır (Koskinen, 1994/2002: 447-448); yaşanmış fakat aynı olmayan benzerlikler différance kavramı içinde toplanmıştır. $\mathrm{Bu}$ anlamda Derrida, göstergeyi bir "iz" varlığı olarak yeniden tanımlamaktadır. Ayrım, ayrıştırma veya erteleme anlamına gelebilen différance yapısökümcü felsefeye göre, bir "yokluk-mevcudiyet" oyunudur (Derrida, 1999: 78-79); böylelikle anlam zamanla değişebilmektedir.

Metinlerin daha önceki metinlerin yankılarıyla dolu olmaları, onlardan izler taşımaları ve de henüz gerçekleşmemiş gelecekteki potansiyel bağlamlarla ilişkilendirilebilmeleri postmodernist söylemin başlıca temalarıdır. Bu temalar aynı zamanda çeviri ediminin de paradoksları ve zorluklarıdır. Postmodern söylemin metinlerin yeniden yazılma sürecinde gizli kalmış anlam katmanlarının açı̆̆a çıarıldı̆̆ını savunması, ayrıca metinlerin yeni bakış açılarıyla okunmasını hedefleyen yapıbozum felsefesi gereği dilde anlamın sinırsızlı̆̆ını öngörmesi (Sarup, [1997] 2004: 80), çevirinin günümüzde ilgilendiği temel meseleler haline gelmiştir. Denilmek istenen ile söylem arasında kalan anlam açmazlarını, bir başka ifadeyle "kör noktaları" (aporia) tespit edip onları açıklı̆̆a kavuşturmak çevir(men)inin görevidir (Eagleton, 1990: 155-156). Buna karşllık postmodernist söylem, metinler arası ilişkileri incelemek veya yeniden düşünmek için çeviriyi bir araç olarak kullanmaktadır.

8o'li yıllarda çeviri çalışmalarında postmodern eğilimleri görebilmek mümkündür; çevirinin sosyal, politik, kültürel ve özellikle manipülatif boyutlarının ön plana çıktığı çeviri tarihinin "kültürel dönemeç" olarak bilinen bu döneminde çeviri, iktidar ve ideoloji meseleleriyle ilişkilendirilmiştir (Bassnett, 1993: 147). Söz konusu tarihsel süreçte, çoğulculuk kavramı sadakat dogmalarının yerini almış ve kaynak metne veya orijinallik fikrine farklı açılardan meydan okunmuştur. İlerleyen süreçte çeviribilimdeki postmodern eğilimler kendilerini, sömürgecilik sonrası (postkolonyal) çeviri (Spivak, 1988; Bhabha, 1994) ve feminist çeviri (Godard, 1984; Chamberlain, 1988) gibi iki belirgin postmodern akımla hissettirmiştir. Çeviri eyleminde gözlenen postmodern eğilimlerden yapısökümcü yaklaşım, hiyerarşik karşıtlıkları ortadan kaldırmaya yönelik çabasıyla özellikle ön plana çıkmış ve yazar-çevirmen ilişkisinin yeniden düşünülüp revize edilmesi için kendisinden faydalanılmıştır.

Özetle, postmodern eğilimlerin çeviribilime olan kapsamlı katkıları, çeviriye kendi kapasitesini açıklama fırsatı sunmakta ve çok kültürlü ve disiplinler arası bu akademik çalışma sahasında karşılaşacak zorlukları aşma imkânı tanımaktadır.

\section{4. Çevrilemezlik kavramına genel bir bakış}

Çeviri kuramcılarının belki de en çok tartıştığı konulardan biri çevrilemezlik kavramıdır. Kavram olarak çevrilemezlik, çevrilebilirlik kavramına zıt olarak algılanmaktadır. Çeviriyi "kültürel aktarım birimlerine" (memes) ayırarak analiz eden Andrew Chesterman çevrilemezlik kavramını, "bir üst düşünce birimi” (supermeme) olarak tanımlamaktadır (2016: 6).

Batı çeviri geleneğinde Wilhelm von Humboldt'un dil-düşünce ilişkisini ön plana çıkararak başlattığı tartışma günümüze kadar uzanmaktadır. Dolaylı anlatım biçimini yansıtan çevrilemezlik tartışması, modern çeviribilim çalışmalarında felsefi bir sorgulama görünümündedir (Venuti, 200o: 51). Bu felsefi sorgulama içinde ontolojik içeriklerin ağır bastığı görünmektedir. Anlam ve sözdizim bu içeriklere yön 

1300)

vermektedir. Çeviri, iki farklı anlam vurgusu yapmaktadır. Bunlardan biri niteliğe, diğeri olguya dayalıdır. Çevrilemezlik bu iki anlam vurgusu arasındaki ara yüzü yansıtmaktadır.

Anlamı oluşturma ve oluşturulan anlamı aktarma çabaları, çeviri tarihi boyunca ikili bir karşıtlıkla anılmaktadır: langue-parole (dil-söz). Saussüre ile başlatılan ve Jakobson ile genişletilen bu ayrıma göre dil, artzamanlı ve eşzamanlı eksenler üzerinde ilerlemektedir. Eksenler belli ön koşullarda kesişmekte ve bu kesişmeler sonucunda anlam daralmaları ve/veya genişlemeleri yaşanmaktadır (Jakobson, 1959: 67-68/122-123).

Johann Gottfried Herder, Wilhelm von Humboldt ve Friedrich Schleiermacher gibi Alman filozoflar çevrilemezlik tartışmasını daha çok çeviri metotlarının kapsamında ele almışlardır. Dil-düşünce etkileşimine dayanarak çevrilemezliği çevirinin imkansızlı̆̆ görüşüyle ilişkilendirmişlerdir. On sekizinci yüzyılın sonlarına kadar asıl soru hiçbir zaman, kaynak ve erek kültürler/ diller dikkate alınarak, metnin çeviriye yatkınlı̆ını, bir başka ifadeyle, çevrilebilirliğini araştırmak olmamıştır. Tartışma boyunca daha çok metnin erek dile en iyi nasıl çevrilebileceği sorusuna cevap aranmıştır.

Genel olarak dilsel ve kültürel farklılıklar aşılamaz engeller olmasalar da, dilin bir düşünceyi yansıtması ve çevirinin bu çerçeve içinde varlığını sürdürmesi, meselenin esası kabul edilmiştir. Humboldt'unki başta olmak üzere yirminci yüzyıla taşınan baskın bakış açısı, her dilin kendi dünya görüşü olduğu varsayımından dolayı, dillerin dolayısıyla metinlerin (kusursuz) çevrilemez oldukları yönünde gelişmiştir (Humboldt, 1816: akt. Lefevere,1977: 40).

Benzer görüşü benimseyenlerden Roger Bacon, monadist ${ }^{3}$ yaklaşımıyla dillerin kendilerine özgü niteliklerini başka bir dil içinde korumayacaklarını savunmaktadır (Opus Majus III, 1928: 7536). Buna rağmen Bacon, evrenselci ${ }^{4}$ yaklaşım çerçevesinde dillerin evrensel bir dilbilgisine sahip olduğunu ileri sürmektedir. Bacon'a göre dil, yüzey yapı ve derin yapı olmak üzere, iki katmandan oluşmaktadır; derin yapıdaki düşünce, dilsel unsurlar sayesinde, yüzey yapılara dönüşmektedir (1928: akt. Robinson, 1991: 45).

Genel hatlarıyla herhangi bir dildeki anlamın, diğer bir dile, köklü bir değişikliğe uğratmadan transferi olarak yaklaşılan ve anlaşlan çeviride, ilk temel ikili karşıtlık (Pym \& Turk, 1998/2001: 273) söz konusu transferin sözcüğü-sözcüğüne mi, yoksa anlamı-anlamına mı gerçekleştirileceği konusunda yaşanmıştır. Marcus Tullius Ciceró kaynak metnin verdiği etkinin erek kültürde oluşturulmasının, ancak anlamına göre çeviri anlayışılla sağlanabileceğini savunarak (Bassnett, 2002: 52), bir yandan "sadıkserbest” çeviri kutuplaşmasını başlatmış diğer yandan çevirilebilirlik-çevrilemezlik polemiğinin öncülerinden olmuştur (Schulte \& Biguenet, 1992: 2).

$\mathrm{Bu}$ ikilem sonucunda, kaynak metne sadakat veya erek metin okuruyla tam uyum gibi mutlak uçlar çeviriyi bir yandan sınırlamış ve diğer yandan çevirinin sınırlarını belirsiz kılmıştır. Çevirinin sınırlarını belirlemeye yönelik ilk adımlar daha çok dilbilimsel açıdan atılırken, daha sonraki süreçte bu sınırlar metin türleri geleneği esaslarına göre değerlendirilmiştir. Çevirinin kültürel dokusunun ön plana çlktığ 1 kültürel süreçle birlikte, çevirinin dil ve kültürden bağımsız düşünülemeyeceği öngörülmüss ve bu öngörü içinde çeviri pratiği, politika-güç ilişkileri ve çeviri etiği gibi yeni çeviri paradigmaları ışı̆̆ında gelişimini sürdürmüştür (Yazıcı, 2005; Snell-Hornby, 2006).

3 Monadist Yaklaşım: çeviriyi mümkün görmeyen veya sorunlu bulan yaklaşım Evrenselci Yaklaşım: çevirebilirliği savunan yaklaşım 
Bir yanda sözcük ve söz dizim düzeyinde dillerin uyuşmazlığının dikkate alındığı dilbilimsel bir çerçeve, diğer yanda kültürler arası farklılıklara dayandırılarak getirilen sınırlar (Mundt, 2019: 65), çevirinin hem birleştirici hem de ayrıştırıcı paradoksal doğasını ayrı ayrı yansıtmaktadırlar. Dilsel ve kültürel sınırlamalar nedeniyle, çeviri bazen imkânsız (Derrida, 1985: 120) bazen de "ütopik bir uğraş" olarak nitelendirilmiştir (Ortega y Gasset, ([1937]1992: 93; 2008: 37).

Postmodern felsefe odaklı bir çeviri paradigmasına doğru birer adım olan bu tür sınırlamalar, çevirinin yapılamayacağı varsayımını bir “ön koşul” olmaktan çıkarmıştır. Aksine çevrilemezlik tartışması bilinçli bir seçim gerektirdiği fikrini temel almaktadır; metnin ruhunu yansıtan özelliklerin çevrilebilmesi için, çevirmenin belli bir olgunluğa erişmesi gerektiği düşüncesi benimsemektedir. Burada sözü edilen ruhun çeviride yansıtılamaması, kaynak metindeki bir eserin sürekli devinim içinde olmasından kaynaklanmaktadır. Bu nedenle hiçbir sözcüğün aynı anlamı taşıyamayacağı vurgulanmaktadır.

Dilin ruhunu yansıtma konusunu tartışan Sapir-Whorf Hipotezine göre, dil-düşünce etkileşimi bireyin dünya görüşünü şekillendirmekte ve aynı zamanda davranışları da etkilemektedir. Dillerin çokluğuyla ortaya heterojen bir panorama çıkmakta ve bu da, kültür ve dil yoluyla edinilen farklı dünya algısının resmini çizmektedir. Sapir-Whorf Hipotezi böylece, farklı dillerdeki insanların farkh dünya görüşlerine (Weltansichten) sahip olabileceği fikrini savunmuştur. Dil-düşünce etkileşimini/birlikteliğini savunan bu görüsse Wilhelm von Humboldt dili yaratıcı bir etkinlik -Energia- olarak niteleyerek destek vermiştir (Humboldt, 1988: 54-55). Humboldt, sözcüklerin gerçek anlamlarında kullanılmadıklarını, aksine simgeler dünyasında kullanıldıklarını düşündüğü için, çevirinin olanaksızlığından söz etmektedir (Humboldt, 1796; akt. Wilss, 1982:35; (Humboldt,1816: akt. Lefevere, 1977:40/1992: 135; akt. Schulte \& Biguenet, 1992:55):

Benzer görüşleri paylaşanlardan Walter Benjamin, çevirinin salt görevini saf dilin (reine Sprache) serbest bırakılması olarak görmektedir. Tüm dillerin birbiriyle uyumlu olabileceğine dair bir yasa öngören saf dil arayışı dillerin bütünlüğüne / birliğine bir gönderme olup diller arası metafizik bağın varlı̆̆ına işaret etmektedir. Benjamin'e göre, çeviride anlam-biçim uyumsuzluğu giderilemeyecek bir sorundur çünkü dil bu sorunu çözmek için yetersiz kalmaktadır (1997: 162). Bunun gerçekleşebilmesinin ancak özgün yapıta dönülmesiyle mümkün olacağını savunan Benjamin, bir üst dilin gerekliliğinin altını çizmektedir (1997: 154). Benjamin, biçimi içerikten daha önemli bulmakta ve çevirinin aslını taklit etmesi gerektiğine inanmaktadır. Kaynak metnin "farklı gözlerle" okunup yeniden çevrilmesi, Benjamin için, diller arası uyumun sağlanması ve temelindeki boşluğun giderilmesi için esastır. Derrida, metnin yeniden okunup yorumlanması esasını, bir başka deyişle Benjamin'in "saf dil" arayışını, différance sözcüğüyle yeni baştan okumaktadır. Buna ek olarak, Benjamin’in dilin herhangi bir nesnel gerçekliğe dayandırılamayacağı öngörüsü, postmodern çeviri yaklaşımının önemli savlarından birini oluşturmaktadır (Bassnett, 1993: 161).

Willard Van Orman Quine çevirilmezlik üzerine uzun soluklu bir tartışma sürdürmüştür. Yirminci yüzyıl Amerikan filozoflarından Quine, dilin kullanımındaki belirsizliklerden hareketle (bkz. Wittgenstein ve dil oyunları ${ }^{5}$ ), mutlak bir çevirinin olanaksızlığı fikrini geliştirmiştir. Quine birbiriyle uyumsuz, fakat her biri sözce ile uyumlu çevirilerin gerçekleştirebileceğini savunmuştur. Buna karşın, tek bir "doğru" çevirinin yapılabilmesini imkânsız bulmuştur. Anlamın dolayısıyla çevirinin belirsizliği teziyle, çevrilebilirliği ontolojik açmazlarıyla ele alan Quine, anlamın varlığını sorgulamıştır (1969: 29-30). Bu

Dil Oyunu (Sprachspiel), Ludwig Wittgenstein’ın geliştirdiği, dilin anlamı dilin kullanılmasıdır şeklinde özetlenebilecek bir felsefe kavramıdır. Wittgenstein'ın ikinci dönem felsefi sorușturmasına ait bu kavramda, kelimeler dinamik bir kullanıma sahiptir ve bir uzlaşım içerisinde, aynı anlam değerine sahip, başka kelimeler yerine kullanılabilmektedir. "Dil oyunu" denen bu sosyal etkinlikte, anlam dilin kullanım kurallarına dönüşmüştür (2009 [197]:86). 

1300)

varlık sorgusunu gerçekleştirirken, ses-kavram bağının mevcut değişkenlere göre anlam kazandığına dikkat çekmek istemiştir (bkz. Quine’in müze metaforu ${ }^{6}$ ).

Ses-kavram ilişkisine dayanarak nesnelerin "nedenli” (sebep-sonuç ilişkisi) veya "nedensiz" (uzlaşıma dayalı) olarak adlandırılmaları (Saussure, 1983: 67, 68-69, 76, 11, 117), Platon’un Cratylus diyaloğunda geçtiği gibi, ikinci dönemindeki Wittgenstein ile Quine'in buluştuğu çizgidir. Her ikisi de dil ile gerçek dünya arasındaki ilişkinin belirlendiği ve dilin kullanım yönüne dikkat çekildiği bu çizgide, anlam belirsizliğini ancak radikal bir çevirinin gidereceğine inanmaktadırlar (Quine, 1960: 26). Bu anlamda yapısökümcü Derrida da dile karşı benzer yaklaşım sergilemiştir.

Derrida ve Wittgenstein geleneksel felsefenin değiştirilemez addedilen ön kabullerini birlikte yerinden sökmüşlerdir (Bannet, 1997: 657). Wittgenstein ve Derrida, çeviri yoluyla dil içi ve diller arası farklı anlam köprülerinin kurulabileceğine ve doğruluğu şüpheli söylemlerin çeviri yoluyla nasıl kurgulanıp aktarılabileceğine, dilin sınırsızlığını açımlayarak ve dilin sosyal-anlık pratikler içerdiğine dikkat çekerek ışık tutmaya çalışmışlardır (Bannet, 1997: 670).

Çevirinin imkânsızlığıyla ilişkilendirilmiş bir diğer kültürel aktarım kavramı "eşdeğerlik" anlayışında, hem sözcük hem de yapı düzleminde, diller arası farklılıklar nedeniyle çevrilemeden geriye bırakılan unsurlar çevrilemezlik kavramının odak noktası görülmektedir. Chesterman'ın bir diğer üst düşünce birimlerinden eşdeğerlik, çeviride kuram arayışları bünyesinde değerlendirilmekte ve erek dildeki metnin bağlamsal anlamı içinde oluşturulma çabasını ifade etmektedir. Bu çabanın başarısız kaldığı her an, dilsel ve kültürel anlamda birer çevirilemezlik durumu olarak kabul görmektedir (Catford,1965: 94). Bunun nedeni, dilsel eşdeğerlilik arayışının çeviriyi, iki farklı dilde kodlanmış iki farklı ileti olarak görmesidir (Jakobson,1959: 233).

$\mathrm{Bu}$ anlayış, çevirideki sözcüğe aşırı bağlılık (metaphrase) veya aşırı serbestlik (paraphrase) (Dryden, 1680: 2004) kutuplaşmasını yansıtan bir farkındalıktır. Söz konusu kutuplaşmaya göre çeviri sorunlu bir eylemdir: bir yanda dilin sistematiği içinde kodlanmış bir dil iletisi, diğer yanda tepkisel ve yaratıcı bir betimleme söz konusudur. Bu anlamda çeviri “dolaylı bir anlatım biçimi” olarak tanımlanmaktadır (Jakobson, 1959:233). Dolaylı bir anlatım biçimi şeklindeki çeviri tanımı, postmodernizm, postyapısalcılık ve yapısöküm gibi bazı kuramsal paradigmalarla çeviri arasındaki organik bağa vurgu yapan bir tanımlamadır.

Anlam üretiminde biçime verilen önem, yapısökümcü Derrida gibi postmodern çeviri yazın kuramcılardan tarafından benimsenmiş ve dilin değil metnin çevrildiğinin altı çizilmiştir. Postmodern kuramcılar, her okumayla yeni bir anlamanın ve anlamlandırmanın oluştuğu şeklindeki yaklaşımlarında, anlamın belirsizliğinin ve dolayısıyla metnin gerçek anlamının sabitlenemez oluşunun üstünde durmuşlardır.

Bu yeni yaklaşımda, özne-nesne ayrımı kalkmış ve gösterilen sınırlarından arındırılmıştır (Eagleton, 1996: 149). Geleneksel metin çözümleme anlayışı yazının yazarından ayrı tutulmasıyla terk edilmiştir (Barthes,1977: 148). Anlamın nasıl üretildiği tartışması, akılcılık ekseninden, son bir okumanın ve anlamanın imkânsızlı̆̆ının tartışıldığı, postmodern söyleme evrilmiştir. Gadamer ve Ricoeur gibi yorumbilgisi (hermeneutik) geleneğin temsilcileri yanında Venuti'nin ve Derrida'nın etkileri, süregelen

Quin'in 1958 yllında Royaumont Konferansında ve Ontological Relativity (1969) adlı kitabında kullandı̆̆ müze metaforunda (the museum myth), "anlam" idealar müzesinde bir numunedir ve bu numune uygun bir açıllama ile etiketlenmiştir. Bu müzede kelimeler birer etiket, "anlam ise sergilenen numunedir. 
tartışmayı, çevirinin imkânsızlığı etrafında biçimlendirmiştir; diller çevrilebilir olmalarına karşın çevrilemez unsurlar taşımaktadırlar (Berman, 1992: 126).

Çevirinin sosyal, kültürel ve politik boyutu bu çevrilemez unsurları daha da belirginleştirmektedir. Çeviri sürecini kendi söylem amacına göre doğrudan yönlendiren bu tür çevrilemezlik boyutları birçok alt-unsur içermektedir. Siyasal konjonktür, güç ilişkileri ve ideolojik yaklaşımlar, çeviri metinleri politize edebilmektedirler. Nesnel bilginin, iktidar-güç ilişkileri yardımıyla (Foucault, 1994: 35), sosyal hayatın bir parçası olan çeviri etkinliğini şekillendirmesi, tek taraflı bir çevrilemezliğe yol açmaktadır (Bassnett, 2002: 75). Buna yol açan güçler dengesi, çevirinin kültürel kimlik inşasında oynadığı rolü benimsemektedir (Venuti, 1995: 19). Bu anlamda, "yeniden yazma-yeniden çevirme", farklı seslerin bastırılmasına hizmet ederek, çeviri üzerinden bir otorite kurma ve sosyal bir kimlik oluşturma düşüncesini yansıtmaktadır (Bhabba, 1994: 241).

Sosyal bir kimlik ve kültür inşa etme anlamında "gücün dili” çeviridir (Spivak 200o: 13). Bu bakımdan yerlileştirme (domestication) ve yabancılaştırma (foreignization) çeviri stratejileri, bir kültüre empoze edilen tek yönlü çevrilemezlik durumlarını ifade etmektedir (Venuti, 1998: 80). Yeni bir kültürel kimlik oluşturmak amacıyla yabancı unsurların tutulması veya asimile edilmesi, "kimseye ait olmayan" ya da "herkese yabancı olan" kültürel alanlar oluşturmaktadır (Bassnett, 2007: 22). Kendi kültüründen ve dilinden bir kopuşu, mecazi anlamda dilin sürgün edilişini imgeleyen bu durum, Babil söylencesindeki dağınıklı̆̆ı ve karmaşıklı̆̆ resmetmektedir. Dilsel-kültürel, coğrafi, deneyimsel, düşünsel ve duygusal anlamda yaşanan bu metaforik dağınıklık ve kimlik inşası metinleri çevrilemez kılan unsurlardan ikisidir.

$\mathrm{Bu}$ dağınıklık ve kargaşa metaforu içerisinde, dilin hangi anlama gönderme yaptığının anlaşılması ve amaçlanan etkiyi uyandırması zorlaşmaktadır (Ogden \& Richards, 1946/2002: 277). Özellikle trajik deneyimleri aktarmak (bkz. Auschwitz) ${ }^{7}$, kutsal metinleri yorumlamak ve cinsiyet/etnik ayrımcllk ile ilgili tabuları tanımlamak dilin ve çevirinin imkanlarını test eden çeviri görevleridir. Metnin çevrilebilirliğine anlamsal ve biçimsel kısıtlamalar getiren böyle durumlar aynı zamanda duyusal ve duygusal boşluklara (lacuna) yol açmaktadırlar (Zhelvis, 1977: 136). Zihindeki tasarım ile gerçek dünya arasında kalan ve dilin/çevirinin dolduramadı̆̆ bu tür boşluklar, metnin anlaşılabilmesi için, ilave metin dışı bilgi ve ek duygusal deneyim gerektirmektedir. Erek okurun anlama sınırlarının aşıldığı bu durum, Babil öncesine dönüşü simgeleyen "dillerin dili" olabilecek bir "üst dilin" veya "saf dilin" eksiliğine işaret etmektedir (Lyotard, 1979/1984: xi).

Bir üst dilin ya da zamanın ötesinde veya insan bilincini aşkın bir dilin eksikliği, kutsal metin çevirilerinde de hissedilmektedir. Anlamın doğrudan metinler tarafından temsil edildiğinin ön kabulü kutsal metinleri çevrilemezlik sınıfına sokmaktadır (akt, Long, 2005:209). Kutsal metin çevirileri, "biçim-anlam" (içerik) / "ses-kavram" ayrışmasının anlamı tahrip ettiği endişesini beraberinde getirmektedir. Aktarımların "çeviri-yazım” (bkz: transcription/transliteration) cinsinden yapılmasındaki ısrar bu nedenledir (Dickins, 2002: 41; Kilito \& Hassan, 2008: xix; akt: Aldahesh, 2014: 30, Abdul-Raof, 2001: 35).

Anlam ve biçim düzeylerinde erek okur üzerinde beklenen etki-tepki durumunun karşllanamadığ (Hejwowski, 2004: 129) bir diğer çeviri mecrası yazınsal çeviri alanıdır. Bu mecrada, estetik dil

II. Dünya Savaşı sırasında soykırıma uğrayan Yahudilerden Peter Arnds Auschwitz toplama kampından kurtulan bir olarak Translating Survival, Translation as Survival in Primo Levi's: Se questo è un uomo (2012) isimli bir makale kaleme almış fakat yeryüzünde hiç bir lisanın orada yaşananları tasvir edecek bir güce sahip olmadığı iddiasında bulunmuştur. 

1300)

kullanımı, dilbilimsel /kültürel kavramlar, tarihsel ve yazınsal üslup farklılıkları çevrilmezlikle iniltili sorun kümeleridir (Aksoy, 2002: 83). Çeviri sürecinde, bir dile ait anlam katmanları, başka bir dile ait okuru, kendine ait dilsel öğeler yardımıyla kurguladı̆̆ı değişikliğe yönlendirmektedir. Bu tez/anti-tez olayı çevirinin diyalektiğidir. Bu diyalektik içinde, dilin ana işlevlerinden biri olan "amaçlanan etkinin uyandırılması" için (Ogden \& Richards, 1946/2002: 224) duygu, düşünce ve hayallerin estetik ve yaratıcı bir dille beslenmesi gerekmektedir. Bu noktada dilin imkanları ve okur beklentileri çatışmakta ancak yazara kendi üslubunu gösterme firsatı doğmaktadır (Savory, 1957:58-59). Böylece, metinler arası benzerlikler oluşturularak metni anlamlandırma süreci-yorumlama süreci başlamaktadır (Ernst-August Gutt, 1991: 156-157; Yazıc1, 2005: 145-146)

Yazınsal eserlerde anlamın yorumlanma sürecinin, dile ve kültüre ait yazınsal niteliklerin korunması yanında, okurun tepkisini belirleyen postmodern bir bakış açısına endeksli olduğu görülmektedir. Bu bakış açısına göre, kaynak metin tek ve değişmez bir anlama sahip değildir; metni oluşturan kaynak kültür öğeleri metnin yeniden inşa edileceği kültürün dokusuyla uyuşması / uyuşmaması söz konusudur (Paepcke: akt., Stefanink, B. \& Bălăcescu: 2017: 38). Diller-kültürler arası doku uyuşmasını ve/veya uyuşmazlığını belirleyecek ana etmen anlamlandırma sürecini yönlendiren metne karşı geliştirilmiş önyargılarılardır.

Metin hakkındaki önyargıları Gadamer, "ufukların kaynaşması" tabiriyle vermekte ve anlamın bütünlüğüne vurgu yapmaktadır (1976: 36; 1975/2004: xxxi). Eserin tamamlanabilmesinin anlam ufuklarının kaynaşmasıyla/ metnin yeniden-defalarca çevrilmesiyle mümkün olacağı ön görülmektedir (Berman, 1992: 1-7; akt. Baker \& Saldanha). Bu öngörü kapsamında, her yeni çeviri yeni bir yorum demek olacağından, her yeni yorum sonrası açığa çıkan yeni anlam ufukları ve bağlantılar yapıtın yorumlanma sürecini "ucu açlk" bırakacaktır (Eco, 1989: 25-31). Bu anlamda eser tamamlanmamış ya da tam olarak çevrilmemiş kalacaktır.

Hiçbir eserin tamamlanamayacağını savunan Derrida, çevirinin imkânsızlığını kaynak metnin varlık sorunu haline getirmiş ve çevrilmekte olanın henüz anlamın bulamayan sözcükler olduğunu ileri sürmüştür (Derrida, 1985: 120; Humboldt'un Aeschylus 's Agamemnon çevirisinin önsözü, akt. Schulte v\& Biguenet, 1992: 55). Çevirinin imkansızlığını, "anlama yorumlamadır” yaklaşımına dayandırmıştır (Heidegger, 2008: 411). Derrida’ya göre, metin içinde anlam üreten başka metinler mevcuttur ve bu metinler yapısöküme uğratılarak görünür kılınmalıdır (1978: 292). Bu anlamda, örnek olarak, şïrin yorumlanma sürecinin henüz tamamlanmadığı düşünülebilir çünkü şiir dilsel kodun tüm kurucu öğelerini-retoriğini bünyesinde toplamaktadır: şiir yan anlam, kültürel bağlam, biçim, biçem, sesçil benzerlikler gibi anlam düzeylerinden oluşmaktadır. Özelikle fonolojik sözcük oyunları veya ses benzeşmeleri çeviriyi akustik yanılgılar içerisine sokmaktadır. Bu gibi durumlar metindeki içeriğin ve üslubun çeviriye doğrudan aktarımını engellemektedir. Ortaya çıan estetik ve yaratıcı kaygılarla birlikte (Connolly, 1998: 174), eserin gerçek anlamıyla anlaşılması zorlaşmakta ve bu nedenle eser defalarca çevrilmek zorunda kalabilmektedir (Baker, 1998: 171; Bellos, 2012: 80).

Buradan çevirinin sadece sese (söze) indirgenemeyeceği şeklinde bir çıarım yapmak mümkündür. Metnin bir bütünlük içerisinde yorumlanmasını esas alan bu çıkarıma göre, şiirin çağrı işlevli dilini biçim ve içerik dengesinde tutmak ve yorum imkanlarını daraltmaksızın, dilin ekonomisi içinde aktarabilmek çevirmenin özgünlüğüyle ilgilidir. Bu özgünlük çevirmeni zaman zaman, derin anlamı korumak için yüzey anlamı değiştirmek gibi, belli tavizler vermek zorunda bırakmaktadır; çeviriyi “yeniden yazma” etkinliğine dönüştürebilmektedir (Eco, 2001: 31). 
Çevrilemezliğin söz konusu olduğu sanatsal (kurmaca) metinler, duygu, düşünce ve belli bir dünya görüşünü estetik bir bütünlük içerisinde aktarma çabası içindedirler; okur üzerinde, ses-kavram ilişkisine ve dil kullanımına dayalı retorik bir etki bırakmayı amaçlamaktadırlar. Bu bağlamda çeviriye yaratıcılık edimi katılmaktadır. Buna ek olarak, ikonik ve sembolik uzamda kurulan ses-anlam ilişkileri, çağrıştırdı̆̆ı anlam çeşitliliğiyle, yeni okumalara/çevirilere yol açmaktadır. Dil oyunu içinde ve dildeki ifade ediliş biçimine göre anlam, yenilenerek değişmektedir.

Anlamın aktarılırken değişmesini “dönüşüm” metaforuyla veren Derrida (1998: 56-57) ve dillerin çeviri yoluyla "dönüştüğünü” söyleyen "saf dil” arayışındaki Benjamin, epistemolojik ve daha çok ontolojik olgular içeren çevrilemezlik tartışmasında yönlendirici isimler olmuşlardır (Tyulenev, 2010: 355). Alman Romantiklerin başlattığı çevrilemezlik tartışmasına Saussure, Aristoteles, Hegel, Heidegger ve Gadamer gibi birtakım filozoflar da dahil olmuşlar ve her biri anlamın "anlaşılmaz karakterini” anlaşılır kılmak için çevrilemezlik kavramı üzerinden söylem geliştirmişlerdir.

\section{Tartışma ve sonuç}

Çevrilemezlik kavramı, dillerin çokluğu esasına dayanarak, metni heterojen bir yaklaşımla ele almakta ve çevirinin doğası gereği, kendini, -farklılıklar- üzerine inşa etmektedir. Derrida’ya ait, "çeviri daima ve sadece çevrilemezi çevirir” söyleminin esasında bu farklılık yaklaşımı yatmaktadır (2000: 17). Bu söylem aynı zamanda, çevirinin bir tercih ürünü olduğunu ve her tercihin bir dışlama içerdiğini anlatmaktadır. Çevirinin dışladığından farklı fakat dışladığından parçalar içeren ürünler üretmesi, göstergelerin başka anlam bağlamlarından geçerek yeni anlamlara geldiğinin bir işaretidir. Gösteren ile gösterilenin bir devingenlik içerisinde sürekli yer değiştirmesinin neden olduğu bu durum anlamın sabitlenemez olduğu anlayışını geliştirmektedir. Anlamın tek bir gösterenle sınırlanamaması anlamına gelen bu anlayış çevrilemezlik kavramının tanımlanma sürecinin önemli bir parçasını oluşturmaktadır (Derrida, 1997; akt. Koskinen, 1994/2002: 447). Gösterilenin sonsuz bir devinim içinde olduğunu ön gören bu süreçte örtüşmeyen içerikler bulunmakta ve buna bağlı olarak, zihinsel, duygusal ve deneyime dayalı iletişimsel kopukluklar yaşanmaktadır. Çevrilemezlik, insanlar arası düşsel ve düşünsel irtibatın kurulmasını güçleştiren örtüşmeyen içerikleri vurgulamaktadır.

Diller arası tipolojik farklılıklar bu tür iletişimsel güçlüklerin yaşanmasına neden olan faktörlerin başında gelmektedir çünkü tipolojik farklılıklar söz konusu olduğunda, neyin ifade edildiğinden çok ifade ediliş şekli kısıtlanmaktadır. Bu kısıtlama, farklı dünya gerçeklerinin dolayısıyla deneyimin belli dil kodlarıla düzenlenmesini ve onların aktarılmasını güçleştirmekte ve "dillerin ancak aktarmak zorunda kaldıklarıyla birbirlerinden farklılaştıkları” esası gerçekleşmemektedir (Jakobson,1959:234236). Çeviriyi ütopik bir uğraş olarak gösteren de ifade edilemeyen, farklılığın ortaya koyulamadığ hakikat ile ilgili durumlardır; anlamın şartlara ve yorumlara bağlı olarak değişebileceğinin bilinmesidir. Çevirinin ütopik bir uğraş olarak addedilmesiyle görünüşte çeviriye getirilen kısıtlama aslında çeviriye bir devingenlik kazandırmaktadır. Çevirinin kazandığı bu devingenlik, bitmeyen bir metin okuma dolayısıyla çevirme sürecini temsil etmektedir. Çevrilmezlik kavramı zihinsel yanılgıların söz konusu olabileceğinden tek bir doğru çevirinin olanaksızlı̆̆ının ve anlamın kesinliğinden söz edilemeyeceğinin adresidir. Çevrilmezlik olgusu, çeviriyi bitmeyen bir anlam arayışı içinde gerçekleştirme çabasını metni yoruma açık tutarak göstermekte ve böylece anlamın ertelenişini resmetmektedir (Barthes, 1968/1977: 146-147; Derrida, 1997: 158).

İfade etmekteki sınırlama sonu gelmeyen anlam üretme çabasını tetiklemekte ve bunu anlamın ertelenme süreci takip etmektedir. Bu sürecin bir parçası olan deneyiminin aktarılmaz oluşu -biricikliği- 

1300)

çevrilemezlik kavramına hem olgusal hem de niteliksel bir anlam kazandırmaktadır. Çevrilemezlik, farklı dil göstergelerinin aynı gösterileni farklı betimlemesine dikkat çekmekte ve bu çabanın altını çizmektedir. Dahası çevrilemezlik, göstergenin değişkenliği bağlamında, yeniden çevirinin hep mümkün olduğunun söylemidir. Buna bağlı olarak çevrilemezlik, anlamın ertelenme durumlarının sebep olduğu kaynak metinden farklı olmayan, ancak aynı sayılmayan paradoksal ya da göreli durumlara farkındalık oluşturma gibi bir işleve sahiptir. Çevirinin paradokslarından ve/ veya açmazlarından biri olan bu durum, yani metinlerin daha önceki metinlerden izler taşımaları, postmodern söyleminkiyle örtüşmektedir.

$\mathrm{Bu}$ şekilde metinlerin her okumada devinimsel olarak yeniden yazılma/ inşa edilme süreci başlamaktadır. Bu süreç zarfında ortaya çıkan yeni anlam katmanları metinlerin yeni bakış açılarıyla okunmasına yol açmaktadır. Bu durum yapıbozumcu geleneğin öngördüğü dilde anlamın sınırsızlık halidir; denilmek istenen ile söylemin kendisi arasındaki anlam potansiyellerini ve dolayısıyla anlam açmazlarını ortaya çıkarma, anlamın devingen ve çok katlı yapısını detaylandırılma çabasıdır. Bu çaba, çevrilemezliğin sınırlarının daha belirgin olarak çizilebilmesi adına hem çeviri hem de postmodern söylem için gerekli bir bileşendir.

\section{Kaynakça}

ACLA Conference (2010). The translation of philosophy and the philosophy of translation: Annual meeting the American comparative literature association creoles, diasporas, cosmopolitanisms. New Orleans, Louisiana April 1-4 https://www.acla.org/sites/default/files/files/Final_Program_Guide_2010.pdf

Abdul-Raof, H. (2001). Qur'an translation: Discourse, texture and exegesis. Routledge

Aktulum, K. (2000). Metinlerarası ilişkiler. Ankara: Öteki Yay

Aksoy, N., \& Aksoy, B. (1992). İki aydınlanma. Birikim. 3. 58-61.

Aksoy, N. B. (2002) Geçmişten günümüze yazın çevirisi. Ankara: İmge Kitabevi.

Aldahesh, A. Y. (2014). (Un)Translatability of the Qur'ān: A Theoretical Perspective. International Journal of Linguistics, 6 (6). ISSN 1948-5425 2014. doi:10.5296/ijl.v6i6.6497

Apter, E. (2013). Against world literature: On the politics of untranslatability. London:Verso

Baker, M. \& Saldanha, G. (2020). Routledge encyclopedia of translation studies. Third Edition. Abingdon: Routledge

Bannet, E.T. (1997). Analogy as translation: Wittgenstein, Derrida, and the law of language. New Literary History. 28(4). Philosophical Thoughts. 655-672

Bassnett, S. (1993). Comparative Literature: A critical introduction. Oxford: Blackwell.

Bassnett, S. (2002). Translation studies. Third edition. London / New York: Routledge

Bassnett, S. (2007). Culture and translation: Why did translation studies take a cultural turn? $A$ Companion to Translation Studies. (yay. haz.). P. Kuhiwczak \& K. Littau. Clevedon: Multilingual Matters Ltd

Bellos, D.(2012). Is that a fish in your ear? Translation and the meaning of everything. London: Penguin

Benjamin, W. (1997). The Translator's Task, Walter Benjamin (Translation) (Çev. S. Rendall). TTR : traduction, terminologie, rédaction, vol. 10, $\mathrm{n}^{\circ} 2.151^{-165}$. http://www.enl.auth.gr/staff/apostolou/the_Translator's_Task.pdf

Berman, A. (1984/1992). The experience of the foreign: Culture and translation in romantic Germany. Albany: State University of New York Press 
Bertens, H. (1995). The idea of postmodern. A history. London and New York: Routledge

Barthes, R. (1968/1977) The death of the author. Roland Barthes: Image Music Text, 142-149. London: Fontana Press

Cassin, B., Rendall, S., Apter, E. S. (2014). Dictionary of untranslatables: A philosophical lexicon. Princeton: Princeton University Press

Catford, J.C.(1965). A linguistic theory of translation; an essay in applied linguistics. Oxford: Oxford University Press

Chesterman, A. (1997). Translating between Aristotle and postmodernism. Mauranen, A. \& T. Puurtinen 1997. Translation - Acquisition - Use. AFinLA Yearbook. Publications de l’Association Finlandaise de Linguistique Appliquée 55. Jyväskylä. 51-6o.

Chesterman, A. (2016). Memes of translation: the spread of ideas in translation theory. Amsterdam/ Philadelphia: John Benjamins Publishing Company

Connolly, D. (1998). Poetry translation. (Yay. haz.) Mona Baker. Routledge Encyclopedia of Translation Studies.170-176. London/New York: Routledge

Davis, K. (2001) Deconstruction and translation. Manchester: St Jerome

Dear, M. J. (1988). The postmodern challenge: Reconstructing human geography. Transactions, Institute of British Geographers NS 13:262-74.

Derrida, J. \& Prenowitz, E. (2008). Who or what is compared? The concept of comparative literature and the theoretical problems of translation. Discourse, (30), 22-53. Wayne State University Press. DOI:10.1353/dis.0.0045 https://edisciplinas.usp.br/pluginfile.php/4313384/mod_resource/content/o/DERRIDA_Who _or_What_is_compared_Concept_of_CompLit.pdf

Derrida, J. (1985). The ear of the other: Autobiography, transference, translation. New York: Schocken Books

Derrida, J. (1982). Margins of philosophy. Chicago: University of Chicago Press, 3-27.

Derrida, J. (1978). Writing and difference, (çev. Alan Bass). Chicago: University of Chicago Press

Derrida, J. (1997). Of Grammatology. (Corrected Edition). İng. Çev. Gavatri C. Spivak. Baltimore and London: The John Hopkins University Press

Derrida, J. (1999). Differance. Toplumbilim, (Önay Sözer, Çev.), Bağlam yay. (10), 49- 61.

Dickins, J., Hervey, S., Higgins, I. (eds). 2002. Thinking Arabic translation - A course in translation method: Arabic to English. London: Routledge.

Dryden, J.(2004). From the preface to ovid's epistles. The Translation Studies Reader. 2nd ed. Ed. Lawrence Venuti. New York: Routledge, 2004. 38-42. Print. https://books.google.com.tr/books?id=7PxeAAAAcAAJ\&printsec $=$ frontcover\&hl=tr\&source $=g b$ s_ge_summary_r\&cad $=0 \# \mathrm{v}=$ onepage $\& \mathrm{q} \& \mathrm{f}=$ false

Eagleton, T. (1996). The illusions of postmodernism. Blackwell Publishing

Ecevit, Y. (2001). Türk romaninda postmodernist açılımlar. İstanbul: İletişim Yay.

Eco, U. (1989). The open work. (çev. Anna Cancogni). Hutchinson Radios. London

Eco, U. (2001). Experiences in translation. Toronto Italian Studies. Goggio Publication Series General Editor: Olga Zorzi Pugliese

Eser, O. (2014). 20.yy. eleştiri kuramlarında çevirmen görünürlüğü. The Journal of International Social Research. 7 (32). 111-116.

Featherstone M. (1988). In Pursuit of the Postmodern: An Introduction. Theory, Culture \& Society.;5(23):195-215. doi:10.1177/0263276488005002001 
Foucault, M., Kelly, M., Habermas, J. (1994). Critique and power: Recasting the Foucault/Habermas debate. Cambridge, Massachusetts and London, England:The MIT Press

Foucault, M., Gordon, C. (1980). Power/knowledge: Selected interviews and other writings, 1972-1977. New York: Pantheon Books

Gadamer, H.-G. (1976). Philosophical hermeneutics: (çev. David E. Linge) Berkeley/London: University of California Press

Gleeson, G., Trinity College Dublin. (2015). Varieties of untranslatability: Exploring a potential system of classification for the discussion of untranslatability in literary texts. Journal of Postgraduate Research,14, 32-48.

Gutt, E.-A. (1991) Translation and Relevance: Cognition and Context, Manchester \& New York: St. Jerome. (2nd edition 2000).

Hassan, I. (1983). Desire and dissent in the postmodern age. Kenyon review, 5.1-18.

Hebdige, D. (1986). Postmodernism and 'The Other Side'. Journal of Communication Enquiry 10/2, 88-100.

Heidegger, M. (2008). Being and time. New York: HarperPerennial/Modern Thought.

Hermans, T. (1997) Translation as institution: translation as intercultural communication: Selected papers from the EST congress Prague 1995. M. Snell Hornby, M. Jettmarova, K. Kaindl (yay.haz.) Amsterdam/ Philadelphia: John Benjamins. 3-20

Humboldt, W. (1988). On language: The diversity of human language-structure and its influence on the mental development of mankind. (çev. Peter Heath). Cambridge: Cambridge University Press

Iser, W. (1995). On translatability: variables of interpretation. The European English Messenger IV (1), 30-38.

Jameson, F. (1994). Postmodernizm. Çev. Nuri Plümer, İstanbul: YKY.

Kilito, A., \& Hassan, W. (2008). Thou Shalt Not Speak My Language. Syracuse, New York: Syracuse University Press. doi:10.2307/j.ctt1pk86bj

Kızıler E. F. (2008). Postmodernist bir yaklaşımla yabancı dil öğretiminde yazının yeri. Akademik Incelemeler Dergisi (AID).3(2).27-42.

Kızıler, F. (2019). Patrick Süskind’in "amnesie in litteris" adlı metninin postmodern yazın bağlamında analizi. International Journal of Economics, Politics, Humanities \& Social Sciences. 2.(4). eISSN: 2636-8137

Kuzıler, F. (2006). Moderniteden postmoderniteye kavramsal bir yolculuk. Patrick Süskind’in parfüm adh romanında postmodernist açılımlar. Erzurum: Salkımsöğüt Yay., 2006.

Küçükalp, K. (2017). Nietzsche ve postmodernizm. İstanbul: Kibele Yaynları

Koskinen, K. (1994/2002). (Mis)Translating the untranslatable: The impact of deconstruction and poststructuralism on translation theory. Meta. 39 (3). https://doi.org/10.7202/003344

Kristeva, J (1980). Desire in language: A semiotic approach to language and art. (trans. Thomas Gora, Alice Jardine and Leon S. Roudiez). ed. Leon S. Roudiez. New York: Columbia University Press

Lefevere, A. (1977). Translating literature: the German Tradition from Luther to Rosenzweig (Approaches to Translation 4). Assen/Amsterdam: Van Gorcum

Long, L. (2005). Translation and religion: Holy untranslatable? Multilingual Matters Limited. Toronto

Quine, W. V. O. (1960). Word and object. Cambridge, MA: MIT Press

Large, D. (2019). Untranslatability:Interdisciplinary perspectives. New York: Routledge

Lyotard, J.-F. (1979/1989). The postmodern conditions: A report on knowledge. Minneapolis: University of Minnesota Press

Moran, D. (2008). Introduction to phenomenology. London: Routledge. 
Mundt, K. (2019) Against the "Un-" in Untranslatability Against the "Un-" in Untranslatability: On the Obsession with Problems, Negativity and Uncertainty. Large, D., Akashi, M., Józwikowska, W., ve Rose, E. (Yay. haz.) Untranslatability: Interdisciplinary perspectives. London: Routledge.

Munslow, A. (1998). Deconstructing history. London: Routledge.

Nietzsche, F. (1873) On truth and lie in an extra-moral sense. (çev.) A. K. M. Adam. Edition 1.o, April 2019.Titling set in Hesse Antiqua Text in Scala 12/16. Oxford: Quadriga

Ogden, C. K., R., I. A., Malinowski, B., \& Crookshank, F. G. (1946/2002). The meaning of meaning: A study of the influence of language upon thought and of the science of symbolism. London: $\mathrm{K}$. Paul, Trench, Trubner \& Co.

Ortega y Gasset, José. (1937/2000). The misery and splendor of translation. (Çev.Elizabeth Gamble Miller) The translation Studies Reader, (Yay.haz.) Lawrence Venuti, 49-63. London: Routledge.

Nietzsche, F. (2002). Güç istenci. (Çev.: Sedat Umran), Birey Yayıncllı, İstanbul

Parla, J. (2000). Don Kişot'tan bugüne roman. İstanbul: İletişim Yay.

Pym, A. \& Turk, H. (1998/2001). Translatability. M. Baker (Yay. haz.) Routledge encyclopedia of translation studies, 273-277. New York /London: Routledge

Quine, W. V. O. (1969). Ontological relativity and other essays. New York: Columbia University Press

Quine, W. V. O. (1960). Word and object. The Massachusetts Institute of Technology. Stanford/California

Robinson, D. (1991). Western translation theory: from Herodotus to Nietzsche. London:Routledge

Roman, J. (1959) On Linguistic Aspects of Translation. In: Venuti, L., Ed., The Translation Studies Reader, Routledge:London,113-118. http://dx.doi.org/10.4159/harvard.9780674731615.c18 . Erişim tarihi. 30.07.2021:

https://www.academia.edu/26570349/Jakobson_Roman_1959_On_Linguistic_Aspects_of_T ranslation

Rorty, R. (1982). Philosophy and the mirror of nature. Princeton, NJ: Princeton University Press

Rorty, R. (1983). Postmodernist bourgeois liberalism. The Journal of Philosophy, 583-589.

Sacks, J. (2011). Untranslatability, or mourning translation. 126, 5. Comparative Literature Issue. 1083-1122. The Johns Hopkins University Press Stable

Sarup, M. (1997). Post-yapısalcılık ve postmodernizm. Çev. B. Güçlü. Ankara: Ark Yay.

Saussüre, F. de ([1916] 1959) Course in general linguistics Bally C., Sechehaye, A., (çev. Baskin, W). New York :Philosophical Library

Saussure, F. de ([1916] 1983): Course in general linguistics (çev. Harris, R.). London: Duckworth

Savory, T. H. (1957). The art of translation. London : Jonathan Cape. SBN 22461309

Schulte, R., Biguenet, J. (1992). Theories of translation: an anthology of essays from Dryden to Derrida. Chicago: University of Chicago Press

Sim, S. (1999). The icon critical dictionary of postmodern thought (Icon Critical Dictionary). Routledge.

Skeggs, B.(1991). Postmodernism: What Is All the Fuss about?. British Journal of Sociology of Education, Vol. 12, 2. 255-267. Taylor \& Francis, Ltd

Smart, B. (1993). Postmodernity: Key ideas. Taylor \& Francis Group, ProQuest Ebook Central, https://ebookcentral.proquest.com/lib/gsutr/detail.action?docID=1111522.

Spivak, G. C.. ( 2000). Translation as culture. Parallax 6 (1):13-24.

Stefanink, B., Bălăcescu, I. (2017). The hermeneutical approach in Translation Studies. 37(3), 21-52. http://dx.doi.org/10.5007/2175-7968.2017v37n3p21 
Timur, K. (1999). Kural tanımayan bir ideoloji: postmodernism. Hikmet-Akademik Edebiyat Dergisi [Journal of Academic Literature], Gelenek ve Postmodernizm Özel Sayısı. 3. 1- 9. https://iwp.uiowa.edu/91st/vol4-num1/translating-culture-vscultural-translation

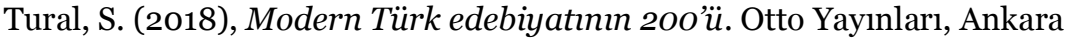

Tyulenev, S. (2010). Is translation an autopoietic system? MonTI 2.345-371. University of Cambridge. DOI: 10.6035/MonTI.2010.2.15.

Venuti, L. (1998). The scandals of translation: Towards an ethics of difference, London \&New York: Routledge

Venuti, L. (1995). The translator's invisibility: A history of translation. London: Routledge

Venuti, L. (2000). The translation studies reader. London: Routledge

Welsch, W. (2002). Unsere Postmoderne Moderne. Berlin: Akademie Verlag

Wilde, A. (1976). Barthelme unfair to Kierkegaard: Some thoughts on modern and postmodern irony. Boundary 2, 5, No. 1 (Autumn, 1976), 45-70. Duke University Press

Wilss, W. (1982). The science of translation: Problems and methods. Tübingen: G. Narr

Wittgenstein, L. (2002). Tractatus logico-philosophicus [1921]. Pears D. F., McGuinness. London/New York

Wittgenstein, L. (1986). Philosophical Investigations. (Çev.:. by G.E.M). Anscombe, Oxford: Basil Blackwell Ltd

Wittgenstein, L. (2009). Philosophical Investigations [1953]. (çev. Anscombe) G.E.M., Hacker, P. M.

Yazıcı, M. (2005). Çeviribilim temel kavram ve kuramları. İstanbul: Multilingual. ISBN975-6542-50-x

Zhelvis, V.I., Markovina, I.Y. (197771979). The experience of systematization of English-Russian lacunae. The

Research on Problems of the Speech Communication.136-146. Moscow: Nauka publishers 